\title{
Cambridge Journals on Linguistics
}

\section{Applied Psycholinguistics}

A new international journal whose scope encompasses work both on normal and on disordered language and communicative functioning and development in adults and children. In addition to full length articles and shorter notes, a special feature of Applied Psycholinguistics is the Editor's Overview which serves an integrative function and helps readers keep abreast of major trends in the field.

$£ 24.00$ for institutions $\mathbf{\$ 1 2 . 5 0}$ for individuals

\section{Journal of Child Language}

The journal publishes material on all aspects of the scientific study of language behaviour in children and the principles which underlie it. In addition to articles and book reviews, the journal contains a Notes and Discussion section, and from time to time an Observations section with short pieces of data illustrating points of general theoretical interest.

$\mathbf{E 2 9 . 0 0}$ for institutions $\mathbf{E 1 5 . 0 0}$ for individuals

\section{Journal of Linguistics}

The Journal of Linguistics is published on behalf of the Linguistics Association of Great Britain. It is concerned with all branches of linguistics, including phonetics. Preference is given to articles of general theoretical interest, but the journal covers as wide a field as possible, and includes articles on a variety of languages, as well as book reviews and a section devoted to comment arising from recent articles.

\$17.00 for institutions

\section{Language in Society}

An international journal of sociolinguistics concerned with all branches of the study of speech and language as aspects of social life. In addition to original articles, the journal publishes book reviews, brief accounts of work in progress, and notes and comments on points arising out of recent publications.

$\mathbf{E 2 6 . 0 0}$ for institutions $\mathbf{£ 1 3 . 5 0}$ for individuals

\section{Language Teaching and Linguistics: Abstracts}

This journal is compiled by the English-Teaching Information Centre of the British Council and the Centre for Information on Language Teaching and Research. It aims to keep teachers and others professionally concerned fully informed of the latest research and developments in the study and teaching of modern languages, including English as a second language.

$\mathbf{£ 1 7 . 0 0}$ for Institutions $\mathbf{£ 9 . 5 0}$ for individuals

For further details write to Journals Publicity

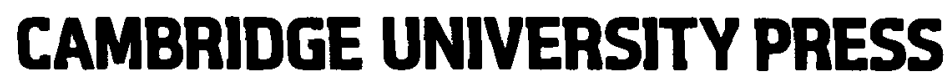

(Publishing Division)

The Edinburgh Building, Shaftesbury Road, Cambridge CB2 2RU, England 


\title{
Applied Language Studies
}

This new series studies the role of language in relation to contemporary social issues, especially those professional activities where language is a primary focus. Such activities include foreign language teaching/learning, mother-tongue education, remedial language studies, speech pathology, language planning, language testing, transiation/ interpreting, stylistics and computational applications.

\section{The Nature of Phonological Disability in Children}

\author{
Pamela Grunwell \\ July/August 1981, c.250pp., £12.80 (UK only) /\$31.00, 0.12 .305250 .5
}

The main aim of the book is to define the ways in which the speech patterns of children with "functional articulation disorders" are deviant from normal patterns of pronunciation. It is shown that such disorders are actually based in the phonological organization of speech production patterns, and that it is only in a linguistic framework that these patterns can be shown to be deviant. The speech patterns of seven children are described in detail using three different frameworks of linguistic analysis.

\section{Academic Press}

A Subsidiary of Harcourt Brace Jovanovich, Publishers London New York Toronto Sydney Sen Franciceo 24-28 Oval Road, London NW1 7DX, England 111 Fifth Avenue, New York, NY 10003, USA 


\section{The Journal of Child Psychology and Psychiatry and Allied Disciplines}

\section{Official Organ of the Association for Child Psychology and Psychiatry}

Joint Editors: L.A. HERSOV, The

Maudsley Hospital, London, UK

M. BERGER, St George's Hospital, London, UK

Corresponding Editors: M. BOHMAN, University of Uneá, Sweden

L. EISENBERG, Harvard Medical School, Boston, USA

N. GARMEZY, University of Minnesota, USA

H. REMSCHMIDT, Phillips University, Marburg, FR Germany
Primarily concerned with child psychology and psychiatry, this journal includes experimental and development studies. An important function of the journal is to bring together interdisciplinary contributions so that more is known about the mental life and behaviour of children. The journal has an international readership and publishes original papers, review articles, book reviews and items of information.

Some Articles Appearing in the Journal:

\section{J. DUNN, C. KENDRICK and}

R. MACNAMEE

The reaction of first born children to the birth of a sibling: mothers' reports S. MITCHELL and P. ROSA

Boyhood behaviour problems as precursors of criminality: a fifteeen-year follow-up study

M.A. STEWART, C. CUMMINGS,

S. SINGER and C.S. DEBLOIS

The overlap between hyperactive and unsocialized aggressive children

\section{Book supplements to the journal AGGRESSION \& ANTI-SOCIAL BEHAVIOUR IN CHILDHOOD AND ADOLESCENCE}

\section{LANGUAGE AND LANGUAGE DISORDERS IN CHILDHOOD}

Edited by L.A. HERSOV, M. BERGER \& A.R. NICOL

Covers recent advances in the field. Topics include theories of language development, educational and social influences, experimental studies in children's verbal communication and home-based treatment of childhood autism.

Contributors include educationalists,
M.E. LYON and R. PLOMIN

The measurement of temperament using parental ratings

J.O. GOLDBERG and

M.M. KONSTANTAREAS

Vigilance in hyperactive and normal

children on a self-paced operant task

This journal is published quarterly.

Annual subscription (1981) US\$80.00 $\$ 36.36$

Two-year rate (1981/82) US\$ 152.00 \&69.09

FREE SPECIMEN COPY GLADLY

SUPPLIED ON REQUEST

Edited by L.A. HERSOV, M. BERGER \&

D. SHAFFER

0080218105 Hardcover US\$11.25 £4.90 171 pages

psychiatrists, psychologists and a physiciar: specializing in the study and treatment of language disorders.

0080252060 Hardcover US\$21.00 $£ 9.25$

0080252052 Flexicover US\$ $9.00 £ 4.00$

Prices subject to change without notice. Sterling prices apply for UK and Eire customers.

Journal prices include postage and insurance.

Headington Hill Hall, Oxford OX3 OBW,

England

Fairview Park, Elmsford, New York

10523, USA 


\section{Journal of \\ Child Language}

Volume 8

I98I

Number I: I-224

Number 2: 225-510

Number 3: $5^{11-66} 3$

Cambridge

at the University Press

I98I 


\section{PUBLISHED BY}

THE PRESS SYNDICATE OF THE UNIVERSITY OF CAMBRIDGE

The Pitt Building, Trumpington Street, Cambridge CB2 IRP

32 East 57th Street, New York, NY 10022

(c) Cambridge University Press 1981

Printed in Great Britain at the University Press, Cambridge 


\section{CONTENTS}

\section{VOLUME 8}

\section{Articles}

Berman, R. A. : Regularity vs anomaly : the acquisition of Hebrew inflectional morphology

Berman, R. A.: Language development and language knowledge: evidence from the acquisition of Hebrew morphophonology

Berninger, G. \& GARVEY, C.: Complementary balance in the use of the interrogative form by nursery school dyads

Bock, J. K. \& HornsBy, M. E.: The development of directives: how children ask and tell

Boysson-Bardies, B. DE, Sagart, L. \& Bacri, N.: Phonetic analysis of late babbling: a case study of a French child

Boysson-Bardies, B. de, Bacri, N., Sagart, L. \& Poizat, M.: Timing in late babbling

CARRELL, P. L.: Children's understanding of indirect requests : comparing child and adult comprehension

Chervela, N.: Medial consonant cluster acquisition by Telugu children

CHIAT, S.: Context-specificity and generalization in the acquisition of pronominal distinctions

Cocking, R. R. \& MCHALE, S.: A comparative study of the use of pictures and objects in assessing children's receptive and productive language

Emslie, H. C. \& Stevenson, R. J.: Pre-school children's use of the articles in definite and indefinite referring expressions

FLeTCHER, P.: Description and explanation in the acquisition of verbforms

Freeman, N. H., Sinha, C. G. \& Stedmon, J. A.: The allative bias in three-year-olds is almost proof against task naturalness

GaLlagher, T. M.: Contingent query sequences within adult-child discourse

KAYE, K. \& ChaRney, R.: Conversational asymmetry between mothers and children

KUCZAJ, S. A.: Factors influencing children's hypothetical reference

McCuNE-NiCOLICH, L.: The cognitive bases of relational words in the single word period

NorLIN, P.F.: The development of relational arcs in the lexical semantic memory structures of young children

OsGOOD, C. E. \& ZEHLER, A. M. : Acquisition of bitransitive sentences : pre-linguistic determinants of language acquisition

RESCORLA, L. A.: Category development in early language

Retherford, K. S., Schwartz, B. C. \& Chapman, R. S.: Semantic roles and residual grammatical categories in mother and child speech: who tunes into whom?

Sinha, C. \& Carabine, R.: Interactions between lexis and discourse in conversation and comprehension tasks

SNYDER, L. S., BATES, E. \& BRETHERTON, I. : Content and context in early lexical development

VeNEZIANO, E.: Early language and nonverbal representation: a reassessment 


\section{CONTENTS}

Vihman, M. M.: Phonology and the development of the lexicon: evidence from children's errors

WARDEN, D.: Children's understanding of ask and tell

Wehren, A., Lisi, R. DE \& ARNold, M.: The development of noun definition

WiNG, C. S. \& Scholnick, E. K.: Children's comprehension of pragmatic concepts expressed in 'because', 'although', 'if' and 'unless'

\section{Review article}

STEIN, D.: Language acquisition and historical change

\section{Notes and Discussion}

Bloom, L., Capatides, J. B. \& TackefF, J.: Further remarks on interpretive analysis : in response to Christine Howe

Cicone, M., Gardner, H. \& WinNER, E.: Understanding the psychology in psychological metaphors

French, L. A.: When does 'when' mean more than 'when'?: a comment on Cairns \& Hsu's stage model for replies to when-questions

GolinkofF, R. M.: The case for semantic relations: evidence from the verbal and non-verbal domains

HoRgan, D.: Learning to tell jokes: a case study of metalinguistic abilities

HowE, C. J.: Interpretive analysis and role semantics: a ten-year mésalliance?

KuczaJ, S. A.: More on children's initial failure to relate specific acquisitions

KULIKowSKI, S.: Possible worlds semantics for early syntax

Lust, B.: Coordinating studies of coordination: a reply to Ardery

MulLS, A. E.: It's easier in German isn't it? The acquisition of tag questions in a bilingual child

MOERK, E. L.: To attend or not to attend to unwelcome reanalyses? A reply to Pinker

PINKER, S.: On the acquisition of grammatical morphemes

SNow, C. E.: The uses of imitation

STRMMER, N.: A note on empiricism and structure-dependence

Tweney, R. D. \& Petretic, P. A.: On the comprehension of comprehension studies: a reply to Gleitman, Shipley and Smith's (1978) criticism of Petretic Tweney (1977)

\section{Reviews}

Bullowa, M. (ed.): Before speech: the beginning of interpersonal communication (A. Gopnik)

CLARK, E. V.: The ontogenesis of meaning (S. A. Kuczaj II)

LEBRUN, Y.: Kind en taal (W. Kaper)

McNeILL, D.: The conceptual basis of language (S. Foster)

NELSON, K. E. (ed.): Children's language (P. Griffiths)

SCHAFFER, D. \& DuNN, J. (eds.): The first year of life: psychological and medical implications of early experience (A. Gopnik)

WATERSon, N. \& SNOW, C. (eds.): The development of communication (C. L. Pye) 


\section{Journal of Child Language}

Volume 8 Number 3 October $198 \mathrm{r}$

\section{Articles}

BÉnédicte de Boysson-Bardies, Laurent SAgart \& Nicole BACRI: Phonetic analysis of late babbling: a case study of a French child

BÉNÉdicte de Boysson-BARdies, Nicole Bacri, Laurent SAgart \& Michel Poizat: Timing in late babbling

EDY VENEZIANO: Early language and nonverbal representation: a reassessment

LyNn S. SNyder, ElizaBeth BAtes \& Inge Bretherton: Content and context in early lexical development

Kristine S. Retherford, Bonnie C. Schwartz \& Robin S. CHAPMAN: Semantic roles and residual grammatical categories in mother and child speech: who tunes into whom?

RUTH A. BERMAN : Language development and language knowledge : evidence from the acquisition of Hebrew morphophonology

\section{Notes and Discussion}

Ernst L. Moerk: To attend or not to attend to unwelcome reanalyses? A reply to Pinker

STAN KULIKOWSKI II: Possible worlds semantics for early syntax

ANNE E. MILls: It's easier in German, isn't it? The acquisition of tag questions in a bilingual child

NATHAN STEMmER: A note on empiricism and structure-dependence

\section{Reviews}

SHAFFER, D. \& DUNN, J. (eds): The first year of life: psychological and medical implications of early experience (A. Gopnik)

MCNeILL, D.: The conceptual basis of language (S. Foster)

Erratum

Index of books received

Cambridge University Press I98I

CAMBRIDGE UNIVERSITY PRESS

The Pitt Building, Trumpington Street, Cambridge CB2 IRP 32 East $57^{\text {th }}$ Street, New York, N.Y.10022

Printed in Great Britain at the University Press, Cambridge 


\section{NOTES FOR CONTRIBUTORS}

Papers, notes and reviews should be sent to Prof. D. Crystal, Department of Linguistic Science, University of Reading, Whiteknights, Reading, Berkshire, England. They should normally be written in English. Major articles should not exceed twenty printed pages.

Three copies of the typescript should be submitted, one of which should be the top copy. Contributions should be clearly typed with double spacing, on one side of the paper only, using a conventional size of paper, preferably $\mathrm{A}_{4}$ (or $2 \mathrm{I} \cdot 6$ by $28 \mathrm{~cm}$ ). Authors should hold one copy for correction of proofs. Footnotes, which should be as few as possible, should be listed, double spaced, on a separate sheet at the end of the article. Tables and figures should be drawn on separate pages at the end of the article. Each table/figure should have a title, and there should be an indication in the body of the text as to placement. Tables and figures should each be numbered independently of examples of utterances, etc. The title-page should include the title, author's name and affiliation, together with the address to which proofs are to be sent. Titles should be so worded that the first part may be used as a running headline (with a maximum length of 50 characters, including spaces). An abstract of the article (max. I20 words) should be typed on a separate sheet.

Chronological age should be stated in years, months and (where needed) days as follows: $4 ; 5.17$. Cited forms should be underlined to represent italicization in print. Translational 'meanings' should be placed within single quotation marks. Emphasis should be marked by the use of small capitals. Phonetic transcriptions should, wherever possible, employ the symbols and conventions of the IPA; they must never be used in footnotes, and should in no case be narrower than absolutely necessary for the purpose.

References are to be made in the text thus: (Neisser 1967: 222). If the author's name is part of the text, the following form should be used: 'Piaget (1967: 13r) investigates...' When a work written by three or more authors is referred to, all names should be given in the first citation, with an ampersand linking the last two; e.g. (Fraser, Bellugi \& Brown I963): in subsequent citations the first name only should be given, with 'et al.' added.

All works referred to should be listed at the end of the article, double-spaced and in alphabetical order. The titles of articles should as far as possible be abbreviated according to the conventions of the Linguistic Bibliography of the Permanent International Committee of Linguists (CIPL). Examples of references (note the use of punctuation marks) are:

Carroll, J. B. (196r). Language development in children. In S. Saporta (ed.), Psycholinguistics: a book of readings. New York: Holt, Rinehart \& Winston.

Lenneberg, E. H. (1967). Biological foundations of language. New York: Wiley.

Oldfield, R. C. \& Marshall, J. C. (eds) (1968). Language. Harmondsworth: Penguin.

Velten, H. V. (1943). The growth of phonemic and lexical patterns in infant language. $\mathrm{Lg}$ x9. $28 \mathrm{I}-92$.

With the exception of the title-page, book reviews should be submitted in the same form as articles. The title-page should be of the following form:

F. Smith \& G. A. Miller (eds), The genesis of language. Cambridge, Mass.: MIT Press, 1966. Pp. xii +400 .

Reviewed by Roger J. WaLES, Psychology Department, University of Edinburgh. 